\title{
Hubungan antara Lingkungan Fisik dengan Kelelahan Kerja Pegawai Produksi di Pabrik Tahu Sutera Galih Dabeda
}

\author{
Gurdani Yogisutanti , Dhony Firmansyah, Suyono \\ Sekolah Tinggi Ilmu Kesehatan Immanuel Bandung, Sekolah Tinggi Ilmu Kesehatan \\ Jenderal A. Yani Cimahi \\ *corresponding author, e-mail: gurdani@yahoo.com
}

Received: 30/10/2019; Published: 13/02/2020

\begin{abstract}
Background: Fatigue is a workplace accident that decreased efficiency and endurance at work. This study aims to determine the factors that influence work fatigue in tofu production workers at the Galih Dabeda Silk Tofu Factory Kampung Cibuntu Bandung. Method: The research was cross sectional design and sample in the form of total sampling with a total of 80 employees. Data collection is done through interviews and direct measurements. Data analysis was performed univariately and bivariately with chi square test and the magnitude of the relationship $(O R)$. Results: Factors related to work fatigue are noise ( $p$-value 0,0001) and lighting ( $p$-value 0,0001 ), but heat stress ( $p$-value 0.532; OR 1.045 95\%; 0.987- 1,112) did not correlate with fatigue. Conclusion: The conclusion that can be drawn from this study is the noise and lighting associated with the occurrence of work fatigue in employees in the factory know, while the heat pressure is not proven to be associated with work fatigue. Suggestions that can be recommended are to provide alternating hours of rest for 30-60 minutes to employees, use personal protective equipment as needed and drink water at least 8-10 glasses a day or 160 $200 \mathrm{ml}$ of water in one day according to their respective needs the worker.
\end{abstract}

Keywords: fatigue; nutritional status; heat stress, noise; lighting

Copyright $\odot 2013$ Universitas Ahmad Dahlan. All rights reserved.

\section{Pendahuluan}

Kelelahan kerja masih menjadi masalah dalam dunia industri karena merupakan gangguan kesehatan yang banyak dialami oleh pekerja yang disebabkan oleh pekerjaannya. Di era industri, tidak semua aktivitas dapat digantikan oleh mesin, terutama dalam industri yang dikelola oleh rumah tangga (home industry). Penggunaan tenaga manusia menjadi yang utama dalam aktivitas produksi yang dilakukan secara manual, berlebihan dan terusmenerus menimbulkan kelelahan kerja yang dapat menyebabkan timbulnya kecelakaan kerja. Lingkungan kerja juga di pabrik tahu merupakan beban tambahan bagi pekerja, terutama dari lingkungan fisik yang meliputi panas, penerangan, kebisingan serta kelembaban yang dapat menyebabkan kelelahan kerja.(1)

Salah satu bidang usaha sektor informal yang berkembang saat ini adalah industri tahu. Industri tahu menggunakan kacang kedelai sebagai bahan baku utama dalam proses produksinya. Sesuai dengan perannya sebagai industri sektor informal, industri tahu mempunyai ciri-ciri dalam aspek keselamatan dan kesehatan di tempat kerja. Ciri-ciri tersebut seperti timbulnya risiko bahaya pekerjaan yang tinggi, keterbatasan sumber daya dalam mengubah lingkungan kerja dan menentukan pelayanan kesehatan kerja yang adekuat, rendahnya kesadaran terhadap faktor-faktor risiko kesehatan kerja dan kondisi pekerjaan yang tidak ergonomis, kerja fisik yang berat dan jam kerja yang panjang.(2) Penelitian sebelumnya mengatakan bahwa proses pembuatan tahu terdiri dari beberapa tahap, yaitu: pembersihan kedelai, penggilingan kedelai yang sudah bersih, kemudian kedelai tersebut dimasak dan disaring. Setelah itu dilakukan proses mencetak tahu. 
Tahapan-tahapan tersebut diikuti oleh hazards yang dapat menimbulkan kelelahan dan kecelakaan kerja, di antaranya: panas dari tungku tempat memasak kedelai kemudian aktivitas memeras ampas tahu yang dapat menyebabkan gangguan pada otot dan sendi karena tidak sesuainya peralatan dengan pekerja.(3)

Banyak faktor penyebab timbulnya kelelahan kerja yang disebabkan oleh lingkungan fisik yang tidak memadai di pabrik tahu, akan tetapi belum banyak penelitian dilakukan pada lokasi tersebut. Apabila dilihat dari alur pembuatan tahu, mulai dari penggilingan kedelai sampai dengan pencetakan tahu, memiliki risiko yang berasal dari lingkungan fisik, yang berasal dari suhu panas, penerangan, dan juga kebisingan. Penelitian sebelumnya mengatakan bahwa variabel yang menjadi penyebab kelelahan kerja pada pekerja tersebut adalah masa kerja, beban kerja.(1) Penelitian lainnya juga mengatakan bahwa yang menjadi penyebab kelelahan kerja adalah masa kerja, shift kerja serta adanya kebisingan yang ditimbulkan oleh kereta di stasiun.(4) Adapun penelitian sebelumnya mengatakan bahwa kelelahan pekerja pada bagian penjahitan disebabkan oleh usia dan beban kerja. Oleh karena itu, perlu dilakukan upaya penerapan keselamatan dan kesehatan kerja yang baik di tempat kerja untuk mengurangi terjadinya kecelakaan akibat kerja maupun penyakit akibat kerja.(5) Selain itu, penelitian lainnya didapatkan hasil bahwa yang berhubungan dengan kejadian kelelahan kerja adalah adanya beban kerja fisik yang tinggi dan usia pekerja. Usia pekerja mempengaruhi kemampuan dan kapasitas fisik dalam bekerja. Semakin tua umur pekerja, maka akan berkurang kemampuan untuk melakukan pekerjaan berat dan menjadi lebih mudah lelah. Pada penelitian yang dilakukan di pabrik opak di Desa Ngadikerso Semarang, sebanyak 39 orang $(60,9 \%)$ dari 62 responden mengalami kelelahan kerja. Penyebab kelelahan pekerja di pabrik opak tersebut adalah umur, status gizi, kebiasaan makan dan sikap kerja.(6)

Hasil studi pendahuluan yang dilakukan, didapatkan data bahwa di Kota Bandung terdapat sentra industri tahu yang memiliki 408 unit usaha dengan 1518 pekerja yang tersebar di daerah Cibuntu Kota Bandung. Salah satu pabrik terbesar yaitu Pabrik Tahu Sutera Galih Dabeda. Pabrik tersebut memiliki 4 cabang dengan total karyawan 80 orang semuanya laki-laki. Pabrik tahu tersebut mempunyai sistem kerja 2 shift dengan durasi 8-12 jam setiap harinya tergantung dengan target penyelesaian produksi. Rata-rata target pengerjaan sekitar 5-6 ton kacang kedelai dalam satu hari, dengan jam istirahat yang fleksibel dan bergantian satu sama lain agar produksi tidak terhenti. Hasil wawancara kepada beberapa pegawai pabrik tahu didapatkan informasi bahwa tidak ada makan siang atau makan malam yang diberi oleh pabrik tetapi para pegawai diberi uang makan setiap minggunya. Keluhan yang dirasakan oleh pekerja di antaranya adalah: merasa lemas, sakit kepala, sulit berkosentrasi, mudah mengantuk, pinggang, pergelangan tangan, kaki dan timbul kesemutan serta rasa gatal pada sela-sela jari. Pekerjaan yang dilakukan di bagian produksi mulai dari penyaringan, penggilingan, pencucian, pemasakan, penggumpalan, pembungkusan dan pengepresan serta penggaraman. Dari alur tersebut dapat diketahui bahwa terdapat hazard lingkungan fisik yang dapat menjadi beban tambahan bagi pekerja di pabrik tahu bagian produksi yang dapat menimbulkan kelelahan kerja. Seperti hasil penelitian yang dilakukan di Pabrik Tahu CV Budi Sari Jaya, didapatkan hasil bahwa Iklim kerja fisik pada area produksi yang tidak sesuai NAB yaitu area operator mesin uap dengan ISBB $35,1^{\circ} \mathrm{C}$ dan area pemasakan tahu dengan ISBB $30,5^{\circ} \mathrm{C}$ dengan total 8 orang pekerja, sebanyak $75 \%$ mengalami kelelahan tingkat berat. Penelitian membuktikan bahwa kelelahan kerja subjektif berhubungan dengan iklim kerja lingkungan fisik yang dirasakan pekerja.(7)

Berdasarkan latar belakang dan penelitian yang telah dilakukan di pabrik tahu diketahui bahwa pekerja pada pabrik tahu berisiko mengalami kelelahan kerja yang dapat disebabkan oleh faktor lingkungan fisik. Selain itu, masih kurangnya penelitian yang dilakukan pada pekerja di pabrik tahu dan lingkungan kerjanya terutama lingkungan fisik yang meliputi pencahayaan, tekanan panas dan kebisingan, maka peneliti tertarik untuk melakukan penelitian tentang hubungan antara lingkungan fisik dengan kelelahan kerja pada pekerja di di Pabrik Tahu Sutera Galih Dabeda kampung Cibuntu Kota Bandung.

\section{Metode}

Penelitian ini menggunakan pendekatan cross-sectional, untuk mempelajari dinamika korelasi antara variabel bebas yaitu: kebisingan, pencahayaan, tekanan panas dengan 
kelelahan kerja pada pegawai pabrik tahu. Pengukuran kebisingan menggunakan sound level meter, pencahayaan menggunakan luxmeter, tekanan panas menggunakan thermal environment monitor dan kelelahan kerja menggunakan alat reaction timer Lakassidaya $\mathrm{L} 77$, yang telah dikalibrasi dengan nomor sertifikat: 1999/KAL/AK/VII/2019. Kelelahan kerja dibagi menjadi beberapa kategori, yaitu: 1) kelelahan berat ( $\geq 580$ milidetik); 2) kelelahan sedang (410-579 milidetik; 3) kelelahan ringan (240-409 milidetik) dan 4) normal (150-239 milidetik) (9). Kebisingan dibagi menjadi 2 kategori, yaitu: 1) bising (>85 dB) dan 2) tidak bising ( $\leq 85$ $\mathrm{dB}$ ). Penerangan dibagi menjadi 2 kategori, yaitu: 1) penerangan tidak ideal (>100 lux) dan 2) penerangan ideal ( $\leq 100$ lux). Tekanan panas dibagi menjadi 2 kategori yaitu: 1) terpapar tekanan panas $\left(>28^{\circ} \mathrm{C}\right)$ dan 2$)$ tidak terpapar tekanan panas $\left(\leq 28^{\circ} \mathrm{C}\right)$. Pengukuran tekanan panas dilakukan satu kali selama 1 jam, pada pukul 11.00 wib untuk menggambarkan keadaan lingkungan yang sebenarnya karena pada waktu tersebut pekerja melakukan aktivitas yang cukup tinggi.

Sampel diambil dengan teknik purposive sampling, dengan kriteria inklusi yaitu: pegawai dalam kondisi sehat dan kriteria eksklusi yaitu pegawai yang memiliki riwayat penyakit berat, seperti: penyakit jantung, stroke maupun gagal ginjal. Berdasarkan kriteria tersebut, terdapat 8 orang pegawai menderita sakit pada saat penelitian, sehingga jumlah responden penelitian dari jumlah 80 orang menjadi sebanyak 72 orang. Pengukuran kebisingan dilakukan 12 kali selama 1 menit. Pengukuran dilakukan di titik pusat ruangan. Hal tersebut bertujuan agar dapat menggambarkan keadaan lingkungan perusahaan secara keseluruhan. Pengukuran intensitas penerangan dilakukan satu kali selama 5 menit (didapat nilai angka yang stabil). Luas dari tempat pembuatan tahu rata-rata $100 \mathrm{~m}^{2}$, maka pengukuran dilakukan pada setiap $3 \times 3 \mathrm{~m}$. Pengukuran kelelahan ini dilakukan pada responden sebelum dan selesai bekerja. Pengukuran lingkungan fisik bekerja sama dengan balai Hiperkes dan K3 Kota Bandung. Analisis bivariat menggunakan tabel silang, dan uji statistik yang digunakan adalah Chi Square untuk mengetahui hubungan antara variabel bebas dan terikat yang telah diubah skalanya menjadi skala Nominal. Penelitian ini telah mendapatkan surat keterangan layak etik dari Komite Etik Penelitian Kesehatan Sekolah Tinggi IImu Kesehatan Immanuel Bandung nomor 002/EC/STIKI/B/VI/2019.

\section{Hasil dan Pembahasan}

3.1. Hasil

3.1.1 Pengukuran Kelelahan Kerja dan Lingkungan Fisik (kebisingan, pencahayaan dan tekanan panas)

Pengukuran kelelahan kerja terhadap 72 responden menggunakan reaction timer Lakassidaya L77. Hasil pengukuran menunjukkan sebagian besar pegawai mengalami kelelahan ringan $(63,8 \%)$, sedangkan pegawai yang tidak mengalami kelelahan $(2,8 \%)$. Selain itu, sebagian besar pegawai berada dalam lingkungan kerja yang bising $(97,2 \%)$ dan dengan penerangan yang tidak ideal $(97,2 \%)$, sedangkan kondisi tekanan panas yang dialami pegawai, sebagian besar tidak terpapar tekanan panas $(63,9 \%)$. Secara rinci dapat dilihat pada Tabel 1.

Tabel 1. Distribusi Frekuensi Kelelahan Kerja dan Faktor Lingkungan Fisik pada Pegawai Pabrik Tahu Sutera Dabeda Bandung

\begin{tabular}{lcc}
\hline \multicolumn{1}{c}{ Variabel } & $\mathbf{n}$ & $\%$ \\
\hline Kelelahan Kerja & & \\
Sedang & 24 & 33,3 \\
Ringan & 46 & 63,8 \\
$\quad$ Tidak lelah & 2 & 2,8 \\
Faktor Lingkungan Fisik & & \\
Kebisingan & & \\
Bising & 70 & 97,2 \\
Tidak bising & 2 & 2,8 \\
\hline
\end{tabular}

Disease Prevention and Public Health Journal

Volume 14, Issue 1, March 2020: $30 \sim 36$ 


\begin{tabular}{lcc}
\hline \multicolumn{1}{c}{ Variabel } & $\mathbf{n}$ & $\%$ \\
\hline Pencahayaan & & \\
$\quad$ Penerangan tidak ideal & 70 & 97,2 \\
$\quad$ Penerangan ideal & 2 & 2,8 \\
Tekanan panas & & \\
$\quad$ Terpapar tekanan panas & 26 & 36,1 \\
$\quad$ Tidak terpapar tekanan panas & 46 & 63,9 \\
\hline
\end{tabular}

3.1.2 Hubungan antara Faktor Lingkungan Fisik dengan Kelelahan Kerja pada Pegawai

Hasil penelitian menunjukkan bahwa terdapat hubungan antara kebisingan ( $p$ value $<0,05)$ dan pencahayaan $(p$-value $<0,05)$ dengan kelelahan kerja. Sedangkan tekanan panas $(p$-value $>0,05)$ tidak ada hubungan dengan kelelahan kerja. Secara rinci dapat dilihat pada Tabel 2.

Tabel 2. Tabel Silang Antara Kebisingan, Pencahayaan, Tekanan Panas dengan Kelelahan Kerja pada Pegawai Pabrik Tahu Sutera Dabeda Bandung

\begin{tabular}{|c|c|c|c|c|c|c|c|c|}
\hline \multirow{3}{*}{ Lingkungan Fisik } & \multicolumn{4}{|c|}{ Kelelahan Kerja } & \multirow{2}{*}{\multicolumn{2}{|c|}{ Total }} & \multirow{3}{*}{ OR } & \multirow{3}{*}{$p$-value } \\
\hline & \multicolumn{2}{|c|}{ Lelah } & \multicolumn{2}{|c|}{ Tidak Lelah } & & & & \\
\hline & $\mathbf{n}$ & $\%$ & $\mathbf{n}$ & $\%$ & $\mathbf{N}$ & $\%$ & & \\
\hline \multicolumn{9}{|l|}{ Kebisingan } \\
\hline Bising & 70 & 100 & 0 & 0 & 70 & 100 & & \multirow[t]{2}{*}{0,00001} \\
\hline Tidak Bising & 0 & 0 & 2 & 100 & 2 & 100 & & \\
\hline \multicolumn{9}{|l|}{ Pencahayaan } \\
\hline Tidak ideal & 70 & 100 & 0 & 0 & 70 & 100 & \multirow[t]{2}{*}{-} & \multirow[t]{2}{*}{0,00001} \\
\hline Ideal & 0 & 0 & 2 & 100 & 2 & 100 & & \\
\hline \multicolumn{9}{|l|}{ Tekanan Panas } \\
\hline Berisiko & 26 & 100 & 0 & 0 & 26 & 100 & \multirow{2}{*}{1,045} & \multirow{2}{*}{0,532} \\
\hline Tidak Terpapar & 44 & 95,7 & 2 & 4,3 & 46 & 100 & & \\
\hline
\end{tabular}

\subsection{Pembahasan}

Hasil penelitian yang dilakukan pada 72 pembuat tahu di Pabrik Tahu Sutera Galih Dabeda Kampung Cibuntu menunjukkan 2 orang pegawai yang tidak mengalami kelelahan kerja merupakan pegawai bagian pengemasan yang bekerja di ruang yang memiliki pencahayaan yang ideal, serta jauh dari sumber kebisingan alat, sedangkan pada pekerja yang bekerja di ruangan yang kecil serta dekat dengan sumber kebisingan memiliki kelelahan dalam kategori rendah sampai dengan sedang. Penyebab kelelahan kerja pegawai di antaranya adalah faktor lingkungan fisik. Lingkungan kerja fisik mempengaruhi kelelahan, karena akan menambah beban kerja fisik apabila lingkungan kerja yang meliputi kebisingan, pencahayaan dan suhu dalam kondisi yang kurang baik dan tidak memenuhi persyaratan.(9)

Karakteristik bagian produksi di pabrik tahu sejenis dengan bagian produksi pada pabrik makanan. Hasil penelitian pada pekerja di pabrik kerupuk CV Sumber Barokah Klaten di bagian pengemasan ternyata pekerja tersebut mengalami kelelahan kerja subjektif. Perasaan kelelahan kerja tersebut disebabkan oleh aktivitas yang monoton dalam melakukan kegiatan pengemasan yang dilakukan dalam kondisi panas.(10) Penyebab kelelahan kerja pada jenis pekerjaan yang monoton tidak selalu disebabkan oleh kondisi lingkungan fisik, akan tetapi seperti hasil penelitian yang dilakukan pada perawat di rumah sakit, pekerjaan yang monoton, walaupun dalam lingkungan kerja yang baik masih dapat menyebabkan terjadinya kelelahan kerja subyektif. Artinya kelelahan yang terjadi dirasakan secara subyektif oleh perawat. Apabila diukur secara fisik, 
kemungkinan kelelahan dalam kondisi normal, akan tetapi secara subyektif merasakan kelelahan kerja.(11)

Hasil penelitian ini menunjukkan bahwa tidak ada perbedaan proporsi kelelahan kerja antara pegawai yang berada dalam kondisi tekanan panas yang berisiko dengan yang tidak berisiko. Hal ini tidak sesuai dengan hasil penelitian sebelumnya yang mengatakan bahwa ada hubungan yang cukup erat antara suhu lingkungan dengan kelelahan kerja pada pegawai. Tekanan panas akan memaksa tubuh untuk melakukan adaptasi dengan mengeluarkan keringat yang berlebihan. Pengeluaran keringat tersebut dapat menyebabkan kelelahan kerja. Oleh karena itu, penyediaan air minum yang adekuat dan dalam kondisi yang mudah dijangkau harus disediakan bagi pekerja, untuk mencegah terjadinya dehidrasi dan gangguan akibat tekanan panas dari lingkungan kerja. Periode istirahat yang kurang sesuai dan tidak mencukupi serta asupan nutrisi yang jauh dari kecukupan dapat menjadi penyebab terjadinya kelelahan pada pekerja yang tidak terpapar suhu lingkungan yang panas.(12) Namun, penelitian ini sesuai dengan hasil penelitian lainnya yang menunjukkan bahwa tidak terbukti bahwa tekanan panas dapat menyebabkan kelelahan kerja pada pekerja.(13)

Hasil penelitian ini menunjukkan ada perbedaan proporsi kelelahan kerja antara pegawai yang terkena paparan kebisingan dan yang tidak terkena paparan kebisingan. Kebisingan merupakan bentuk energi yang berbahaya bagi manusia apabila tidak disalurkan pada lokasi yang sesuai. Kualitas perusahaan dapat dilihat dari tingkat kebisingan yang dikeluarkan dari mesin-mesin produksi atau dari peralatan yang digunakan untuk proses produksi. Perusahaan yang memiliki kebisingan tinggi dapat dikatakan merupakan perusahaan yang mempunyai kualitas lingkungan fisik yang kurang baik. Kebisingan yang lebih dari ambang batas sesuai dengan standar dalam Permenaker nomor 8 tahun 2018 dapat menyebabkan dampak buruk bagi manusia dan lingkungannya. Bagi tenaga kerja dapat menurunkan ambang pendengaran dan menyebabkan gangguan kenyamanan dan konsentrasi dalam melakukan pekerjaan. Kebisingan juga dapat menyebabkan terganggunnya sistem keseimbangan tubuh dan juga dapat meningkatkan daya emosi dari pekerja yang terdampak kebisingan tinggi.(9)

Sumber kebisingan didapatkan dari campuran suara pembakaran kayu bakar, pemanasan bahan kedelai serta beberapa kompresor yang sangat dekat dengan tempat pegawai bekerja. Lingkungan kerja yang kurang nyaman dapat memicu timbulnya kelelahan pada tenaga kerja. Kebisingan di pabrik tahu sutera Galih Dabeda melebihi nilai ambang batas, ditambah para pekerja tidak memakai alat pelindung diri berupa ear plug, Kebisingan dapat menurunkan kinerja otot yaitu berkurangnya kemampuan otot untuk melakukan kontraksi dan relaksasi, berkurangnya kemampuan otot tersebut menunjukkan terjadinya kelelahan pada otot yang dapat menyebabkan menurunya produktivitas.(14) Apabila kebisingan dikendalikan dengan baik, maka pekerja dapat bekerja dengan aman dan nyaman, sehingga produktivitas kerja meningkat. Kebisingan yang ditimbulkan oleh mesin produksi dapat menyebabkan pekerja mengalami kesulitan melakukan komunikasi dan mengganggu sistem pendengaran, sehingga dapat meningkatkan kelelahan kerja pada karyawan. Hasil analisis korelasi antara kebisingan dengan kelelahan kerja diketahui bahwa korelasi bernilai positif atau berkorelasi kuat. Hal ini menunjukkan bahwa pengaruh kebisingan terhadap kelelahan sangat kuat.(9)

Terdapat perbedaan proporsi kelelahan kerja antara pegawai yang tidak terpapar penerangan ideal dan yang tidak terkena paparan penerangan ideal. Penelitian yang dilakukan pada pekerja batik tulis, ternyata terbukti terdapat hubungan yang sangat kuat antara penerangan terhadap kejadian kelelahan. Pencahayaan yang kurang di tempat kerja dapat menyebabkan perasaan tidak nyaman, gangguan atau sakit yang meningkat dari waktu ke waktu dan dapat menyebabkan kelelahan. Hal ini dikarenakan penerangan di tempat kerja merupakan salah satu sumber cahaya yang menerangi benda-benda di 
tempat kerja. Banyak objek kerja beserta benda atau alat dan kondisi di sekitar yang perlu dilihat oleh tenaga kerja. Hal ini penting untuk menghindari kecelakaan yang mungkin terjadi.(15) Pada hasil pengukuran penerangan di pabrik tahu sutera Galih Dabeda Cibuntu didapatkan rata-rata 40,95 lux. Adapun minimal penerangan pada pekerjaan dengan ukuran benda sedang seperti pabrik tahu menurut standar yang tertulis dalam Permenaker Nomor 5 tahun 2018 yaitu 100 lux. Hal ini membuktikan bahwa ruangan yang dipergunakan sebagai tempat produksi tahu Galih Dabeda termasuk dalam kategori gelap. Sebanyak 70 pegawai yang tidak terpapar penerangan ideal semuanya mengalami kelelahan kerja, sedangkan 2 orang pegawai yang bekerja di ruangan dengan penerangan sebesar 105 lux (terpapar penerangan ideal) tidak mengalami kelelahan kerja.

Kondisi penerangan dan pencahayaan yang tidak memenuhi standar dapat menyebabkan kecelakaan kerja dan menyebabkan timbulnya kelelahan mata pada pekerja. Kelelahan mata terjadi karena otot mata harus melakukan kontraksi yang berlebihan untuk menyesuaikan dengan kondisi pencahayaan di lingkungan kerja. Akibatnya, mata menjadi lebih cepat lelah dan dapat mempengaruhi kelelahan kerja secara umum pada pekerja. Pencahayaan yang tidak adekuat juga dapat menyebabkan terjadinya kecelakaan kerja, karena kurangnya penerangan pada peralatan kerja. Kesalahan dalam bekerja meningkat seiring dengan ketersediaan penerangan yang tidak memenuhi standar. Kelelahan yang dialami pekerja dapat menyebabkan menurunnya kualitas dan kuantitas produksi, sehingga dapat menyebabkan kerugian. Kerugian tidak hanya dialami oleh pekerja karena menderita kelelahan dan berkurangnya kemampuan penglihatannya, tetapi kerugian bagi pengusaha, karena barang yang diproduksi menjadi menurun baik secara kualitas maupun kuantitasnya. (15)

Keterbatasan dalam penelitian ini adalah waktu penelitian yang terbatas, sehingga menyebabkan pengukuran tekanan panas tidak melibatkan beban kerja. Pengukuran hanya dilakukan pada 4 titik pengukuran saja, serta tidak dilakukan pengukuran beban kerja dan asupan energi pada pekerja. Masih kurangnya penelitian yang dilakukan di pabrik tahu, sehingga pembahasan yang dilakukan banyak menggunakan perusahaan yang memiliki lingkungan fisik yang sejenis.

\section{Kesimpulan}

Kesimpulan yang dapat diambil dari penelitian ini adalah kebisingan dan pencahayaan berhubungan dengan terjadinya kelelahan kerja pada pegawai di pabrik tahu, sedangkan tekanan panas tidak berhubungan dengan kelelahan kerja. Oleh karena itu, direkomendasikan untuk memberikan jam istirahat secara bergantian selama 30-60 menit kepada pegawai, penggunaan alat pelindung diri sesuai dengan kebutuhan dan minum air putih minimal $8-10$ gelas sehari atau $160-200 \mathrm{ml}$ air dalam satu hari sesuai dengan kebutuhan masing-masing pekerja.

\section{Daftar Pustaka}

1. Hermawan B, Soebijanto S, Haryono W. Sikap dan Beban Kerja, dan Kelelahan Kerja pada Pekerja Pabrik Produksi Aluminium di Yogyakarta. Berita Kedokteran Masyarakat. 2017;33(4):213-218.

2. Djayanti S. Kajian Penerapan Produksi Bersih di Industri Tahu di Desa Jimbaran, Bandungan, Jawa Tengah. Jurnal Riset Teknologi Pencegahan Pencemaran Industri. 2015;6(2):75-80.

3. Oktavia DA, Dwiyanti E. Hubungan Iklim Kerja Fisik dengan Kelelahan Subyektif di Pabrik Tahu CV. Budi Sari Jaya Sidoarjo. Jurnal Penelitian Kesehatan. 2016;14(3):166171.

4. $\quad$ Ningsih SNP. Factors Relating To Work Fatigue in Locomotive Dipo Workers PT. Kereta Api Indonesia (Persero). Journal of Industrial Hygiene and Occupational Health. 2018;3(1):69-82. 
5. Atiqoh J, Wahyuni I, Lestantyo D. Faktor-Faktor yang Berhubungan dengan Kelelahan Kerja pada Pekerja Konveksi Bagian Penjahitan di CV. Aneka Garment Gunungpati Semarang. Jurnal Kesehatan Masyarakat. 2014;2(2):119-126.

6. Deyulmar BA, Suroto, Wahyuni I. Analisis Faktor-faktor yang Berhubungan dengan Kelelahan Kerja pada Pekerja Pembuat Kerupuk Opak di Desa Ngadikerso,Kabuoaten Semarang. Jurnal Kesehatan Masyarakat. 2018;6(4):279-285.

7. Oktavia AD, Dwiyanti E. Hubungan Iklim Kerja Fisik dengan Kelelahan Kerja Subjektif di Pabrik Tahu CV. Budi Sari Jaya Sidoharjo. Jurnal Penelitan Kesehatan. 2016;14(3):166171.

8. Setyawati L. Selintas tentang Kelelahan Kerja, Manajemen Kelelahan Kerja dan Jawabannya. Yogyakarta: Amara Books; 2010.

9. Erliana Cl, Irwansyah D, Abdullah D, Zarlis M. Analisis Pengukuran Beban Kerja Supervisor dan Firemen PT Perta Arun Gas menggunakan Metode Defence Research Agency Workload Scale. Industrial Engineering Journal. 2019;8(2):47-52.

10. Verawati L. Hubungan Tingkat Kelelahan Subjektif dengan Produktivitas pada Tenaga Kerja Bagian Pengemasan di CV Sumber Barokah. The Indonesian Journal of Occupational Safety and Health. 2017:5(1):51-60.

11. Perwitasari D, Tualeka AR. Faktor yang Berhubungan dengan Kelelahan Kerja Subjektif Pada Perawat di RSUD DR. Mohommad Soewandhi Surabaya. The Indonesian Journal of Occupational Safety and Health. 2017;6(3): 365-373.

12. Kusgiyanto W, Suroto, Ekawati. Analisis Hubungan Beban Kerja Fisik, Masa Kerja, Usia dan Jenis Kelamin terhadap Tingkat Kelelahan Kerja pada Pekerja bagian Pembuatan Kulit Lumpia di Kelurahan Kranggan Kecamatan Semarang Tengah. Jurnal Kesehatan Masyarakat. 2017;5(5):413-423.

13. Andriani KW. Hubungan Umur, Kebisingan dan Temperatur Udara dengan Kelelahan Subjektif Individu di PT X Jakarta. The Indonesian Journal of Occupational Safety and Health. 2016;5(2):112-120.

14. Suma'mur. Higiene Perusahaan dan Kesehatan Kerja (HIPERKES). Jakarta: Sagung Seto; 2009.

15. Wiyanti N, Martiana T. Hubungan Intensitas Penerangan dengan Kelelahan Mata pada Pengrajin Batik Tulis. The Indonesian Journal of Occupational Safety and Health. 2015;4(2):144-154. 